\title{
The Preliminary Study About the Involvement of Relaxine in Adverse Effect of Polychlorinated Biphenyls on Bovine Myometrial Contractions
}

\author{
Michał Hubert Wrobel
}

Institute of Animal Reproduction and Food Research, Polish Academy of Sciences, Tuwima Street 10, 10-748 Olsztyn, Poland

Corresponding author: Wrobel MH, Institute of A nimal Reproduction and Food Research of the Polish Academy of Sciences, Tu wima Street 10, 10-747 Olsztyn, Poland, Tel: +48-89-5393118; E-mail: m.wrobel@pan.olsztyn.pl

Rec date: March 21, 2017; Acc date: April 20, 2017; Pub date: April 24, 2017

\section{Abstract}

Polychlorinated biphenyls (PCBs) are a group of synthetic xenobiotics, which were used in lots of industrial applications. Two individual congers (PCB 153 and PCB 77) belong to the most prominent environmental contaminations among PCBs, but they have opposite type of configuration and therefore they can exert a different way of action. Since PCBs increased the force of myometrial contractions, in this work, their effect on myometrial sensitivity on inhibitor of myometrial contractions (relaxine, $\mathrm{RLX}$ ) was studied.

Bovine myometrial cells and strips, and luteal cell at 4-8 month of pregnancy, were obtained accidentally in commercial abattoir. They were treated by PCB 153 and PCB 77 and mRNA expression of RLX receptor in myometrial cells and contractions of myometrial strips as well as the secretion of progesterone (P4) and oxytocin (OT) from luteal cells, were measured under their effect.

Both studied congeners decreased $(\mathrm{P}<0.05)$ the mRNA expression of $\mathrm{RLX}$ receptor in myometrium. Admittedly, both PCB 77 and 153 increased $(P<0.05)$ the basal force of contractions, while RLX showed any effect on myometrial contractions. Studied PCBs increased also $(P<0.05)$ secretion of P4 and OT from luteal cells.

It is suggested that PCBs can decreased the sensitivity of myometrium on RLX but their direct effect on RLX function have to be further investigated.

\section{Keywords: Endocrine Disruption; Pregnancy; Uterus}

\section{Introduction}

Polychlorinated biphenyls (PCBs) are a group of synthetic, chlorinated aryl hydrocarbons, which were extensively used in lots of industrial applications, mainly in transformers, capacitors or as hydraulic fluids, heat exchange liquids as well as plasticizers and others [1]. Because of different degree of chlorination, there are possible up to 209 congeners of PCBs. Among them, 3,3',4,4'-tetrachlorobiphenyl (PCB 77) is one of the most abundant PCB congeners in human milk. This congener is a non-ortho chlorine substituted with coplanar configuration and appear to exert its toxic effects via interacting with the cytosolic aryl hydrocarbon receptor (Ahr). Hence is recognized also as dioxin-like PCBs [2]. Since PCB 77 can affect the cell also through estrogen [3] and glucocorticoid receptors [4], it is recognized as a significant environmental pollutant and endocrine disruptor [3] with a wide spectrum of way of action. Admittedly 2,2 ', 4, 4', 5,5'- hexachlorobiphenyl PCB 153 is also one of the most prominent environmental contaminants, but oppositely to $\mathrm{PCB}$ 77 is classified as di-ortho, non-coplanar, non-dioxin congener of PCBs [5] and is known to have rather estrogenic properties [6]. Even though PCBs production and use were banned in USA and Europe more than three decades ago, they are still measured in environment [7]. Due to their lipophilic nature and resistance for biodegradation, PCBs have been bio-accumulated in animal tissues [8], also in domestic animals $[9,10]$. Therefore PCBs have been also measured in food samples [11] and they can be mentioned as a serious health risk.

Since PCBs accumulation in pregnant uterine muscle is higher than placenta, maternal adipose tissue or fetal blood [12], exposure to $\mathrm{PCBs}$ has been followed by different reproductive disorders. Their affected length of menstrual cycle [13] or pregnancy $[14,15]$ as well as PCBs even increased the frequency of miscarriages in women [16] or monkeys [17]. Next, it was stated that the PCBs treatment has been associated with the increase of frequency or force of myometrial strips contractions in vitro in rats [18] or cows [19], respectively. Finally, it was also suggested that oxtyocin (OT) and prostaglandin (PG) F2, which both are the most important natural stimulators of myometrial contractions, are involved in the adverse effect of PCBs on myometrial contraction [20-23].

The proper regulation of uterine contractility is crucial to achieve the success in reproduction. The postovulatory increase of uterine and oviductal muscle contractions facilities transport of gametes and thereby enable fertilization as well support the labor. However, almost all length of pregnancy needs uterine quiescence $[24,25]$. It is reached by progesterone (P4) block of oxytocin (OT) receptors in the myometrium, [26] and relaxin (RLX), which directly inhibit the uterine contractions, as well it is involved in cervical dilation and relaxation of pubic symphysis [27]. Moreover, RLX induced suppression of OT release from corpus luteum in cow [28]. Bovine corpora lutea from late pregnancy contain active RLX, while there is markedly lower than in swine [29]. Since it was found previously that PCBs increased amount of stimulators of contractions (OT and PGF2), here it was hypothesized that PCBs can increase the uterine 
contractions also by impair the function of inhibitor of myometrial contractility.

The aim of this study was to investigate the effect of PCB 77 and PCB 153 on myometrial reception of RLX signal during pregnancy, and therefore on (a) mRNA expression of receptor of RLX and (b) RLX-inhibition of myometrial strips contractions. Moreover, luteal cells were used as a controls for condition of endocrine function of reproductive system of studied cows (ratio OT:P4). While the effect of PCBs on secretory function of luteal cells was studied additionally. The preliminary study about the involvement of RLX in adverse effect of PCBs on bovine myometrial contractions was also prepared to develop the constructed model to study the effect of chlorinated xenobiotics on the function of reproductive system.

\section{Material and Methods}

\section{Collection and preparation of material}

Bovine uteri and ovaries at 4-8 month of pregnancy were collected accidentally in a commercial slaughterhouse. The stage of pregnancy was identified according to [30]. All materials used in these studies were purchased from Sigma-Aldrich $(\mathrm{PL})$ unless otherwise stated. Each medium was supplemented with gentamycin $(20 \mu \mathrm{g} / \mathrm{ml})$, amphotericin $(2 \mu \mathrm{g} / \mathrm{ml})$ and antioxidants: ascorbic acid $(20 \mu \mathrm{g} / \mathrm{ml}$; Merck, USA), sodium selenite $(5 \mathrm{ng} / \mathrm{ml} ; \mathrm{ICN}, \mathrm{USA})$ and transferrin $(5 \mu \mathrm{g} / \mathrm{ml})$. The media did not contain phenol red.

Myometrial cells were obtained by enzymatic dispersion after the separation of the myometrium from the perimetrium and endometrium. The tissue ( $7 \mathrm{~g}$ from each uterus) was minced with scissors and then digested $\left(2 \mathrm{~h}\right.$ at $\left.38^{\circ} \mathrm{C}\right)$ in oxygenated $\left(95 \% \mathrm{O}_{2}+5 \% \mathrm{CO}_{2}\right.$ ) medium ( $20 \mathrm{ml}$ of $\mathrm{M} 199$ supplemented with $0.1 \% \mathrm{BSA})$ with collagenase $\mathrm{IA}(1.5 \mathrm{mg} / \mathrm{ml})$ and dispase $(0.2$ $\mathrm{mg} / \mathrm{ml}$ Gibco, GB), according to Wrobel \& Kotwica [23]. Luteal cells were obtained by perfusion with collagenase according. Cell viability was estimated by exclusion of $0.04 \%$ trypan blue dye. Only cells showing viability above $80 \%$ were used for further studies. The cells suspensions were transferred into 6 or 48-well plates (Nunclon $\Delta$-Surface, NUNC, NL) for measure the mRNA in myometrium $\left(5 \times 10^{5} / \mathrm{ml}\right.$ of cells) and for measure the OT and P4 level in luteal cells $\left(2.5 \times 10^{5} / \mathrm{ml}\right.$ of cells $)$, respectively. The cells were precultured ( $95 \%$ air and $5 \% \mathrm{CO}_{2}, 100 \%$ humidity, $38^{\circ} \mathrm{C}$; Memmert INCO 180, D) for $96 \mathrm{~h}$ (myometrium) or $24 \mathrm{~h}$ (luteal cells) to allow them to attach to the bottom of the wells. Next, they were washed twice with M199 and the medium was replaced with DMEM/HAM-12 supplemented with $0.1 \%$ BSA.

Three strips (6-7 $\mathrm{mm}$ long and 3-4 $\mathrm{mm}$ wide) of longitudinal smooth muscle were dissected from each myometrium. The strips were immediately incubated $\left(24 \mathrm{~h}, 95 \%\right.$ air and $5 \% \mathrm{CO}_{2}$, $4^{\circ} \mathrm{C}$ ) with treatments immersed in $2 \mathrm{ml}$ of aerated (95\% air and $5 \% \mathrm{CO}_{2}$ ) physiologic salt solution $(116 \mathrm{mM} \mathrm{NaCl}, 4.6 \mathrm{mM} \mathrm{KCl}$, $1.16 \mathrm{mM} \mathrm{NaH}_{2} \mathrm{PO}_{4} \cdot \mathrm{H}_{2} \mathrm{O}, 1.16 \mathrm{mM} \mathrm{MgSO}_{4} \times 7 \mathrm{H}_{2} \mathrm{O}, 21.9 \mathrm{mM}$ $\mathrm{NaHCO}_{3}, 1.8 \mathrm{mM} \mathrm{CaCl} 2 \cdot 2 \mathrm{H}_{2} \mathrm{O}, 11.6 \mathrm{mM}$ dextrose, $0.03 \mathrm{mM}$ CaNaEDTA; $p H=7.4)$, and the force of myometrial strips contractions was measured according to [22].

\section{Treatments}

PCB 153 and 77 were dissolved in DMSO (HPLC purity grade) and studied doses $(0.1-10 \mathrm{ng} / \mathrm{ml})$ were affect neither myometrial [22] nor luteal cells [31] viability in cows. Final concentration of the DMSO in the culture media did not exceed $0.1 \%$. Hence, $0.1 \%$ of DMSO was added to the control samples. While to study the inhibition of contractions, there were used two type of RLX. It was porcine $\operatorname{RLX}(30,60$ and $100 \mathrm{ng} / \mathrm{ml}$ according to Kaczmarek et al. [32], it is $200-500 \mathrm{ng} / \mathrm{ml}$ ) since it was also used in study in beef heifers in vivo [29,33]. Since signaling by Relaxin-2 human through its target receptors enhances the growth of pubic ligaments and ripening of the cervix during birth [34] it was also used in this study (10-400 ng/ $\mathrm{ml})$.

\section{The effect of PCBs on mRNA expression of RLX receptor in myometrial cells}

Myometrial cells from cows $(n=7)$ were incubated $(24 h)$ with PCB 77 or PCB 153 (both at concentration $10 \mathrm{ng} / \mathrm{ml}$ ) and with estradiol (E2; 10-7M). After incubation, the medium was removed, and the cells were covered with Phenozol (300 $\mu$ l for each well; $A \& A$ Biotechnology, $P L)$. The plates were stored at $-70^{\circ} \mathrm{C}$ for subsequent real-time PCR analysis of the mRNA expression of RLX receptor. Total RNA was isolated using the Total RNA Kit (A\&A Biotechnology, PL) according to the manufacturer's instruction. The concentration and purity of the isolated RNA samples were determined using a spectrophotometer (NanoDrop 1000; Thermo Scientific, USA). The absorbance ratio (A260:A280) for all samples was between 1.8 and 2. Total RNA ( $0.5 \mu \mathrm{g}$ for each sample) was reverse transcribed $\left(42^{\circ} \mathrm{C}\right.$ for $\left.1 \mathrm{~h}\right)$ using reverse transcriptase. The TATA box-binding protein (TBP) was used as the most stable housekeeping gene to normalise the gene expression in the bovine myometrium. The primer sequences (RLX receptor predicted to Bos Taurus relaxin/insulin like family peptide receptor 1, variant X1, Accession no. XM 610789.8; Product size: 109; Forward: TCTGCAGTTACGTGCTTTGGA;

Reverse: CAGTCGGCACAGCAGAGAGA; TBP Accession no. NM_001075742; Product size: 194; Forward: CAGAGAGCTCCGGGATCGT;

Reverse: ACACCATCTTCCCAGAACTGAATAT), were synthesised (IBB PAN PL). Real-time PCR ( $25 \mu$ l volume) was performed using the APB Prism 7900 sequence detection system (Applied Biosystems, USA). The reaction mixture contained cDNA $(5 \mu \mathrm{l}$; $200 \mathrm{ng} / \mu \mathrm{l})$, SYBR Green PCR master mix (12.5 $\mu \mathrm{l}$; mix-B, lot. 171011; A\&A Biotechnology, PL), Hi-ROX (0.4 $\mu$; lot. 41011; A\&A Biotechnology, PL), both PCR primers (2.5 $\mu \mathrm{l}$ of each; $200 \mathrm{nM})$ for each studied gene and water $(2.1 \mu \mathrm{l})$. The PCR reactions for each pair of primers were performed as follows: initial denaturation $\left(95^{\circ} \mathrm{C}\right.$ for $\left.10 \mathrm{~min}\right)$ followed by 40 cycles of denaturation $\left(95^{\circ} \mathrm{C}\right.$ for $\left.15 \mathrm{~s}\right)$ and annealing $\left(60^{\circ} \mathrm{C}\right.$ for $1 \mathrm{~min}$ for annealing and extension). Melting curves were set up using stepped increases from 60 to $95^{\circ} \mathrm{C}$ to ensure the specificity of the amplified product. The PCR products were electrophoresed on a $2 \%$ agarose gel to confirm their specificity. 


\section{The effect of PCBs on myometrial contractions}

Myometrial strips ( 3 from each cow) were incubated ( $24 \mathrm{~h}$, $4^{\circ} \mathrm{C}$ ) with PCB 153 or PCB 77 ( $n=4$ cows), each at the dose of 10 $\mathrm{ng} / \mathrm{ml}$, according to Wrobel et al. [22,23]. Next, the myometrial strips were individually placed into the chambers of a HSE Schuler Organbath apparatus (March-Hugstetten, D). Each chamber contained Krebs-Ringer's solution (KRS; $\mathrm{pH}=7.4 ; 10 \mathrm{ml}$ ) composed of $\mathrm{NaCl}(120.3 \mathrm{mM}), \mathrm{KCl}(5.9 \mathrm{mM}), \mathrm{CaCl}_{2}(2.5 \mathrm{mM})$, $\mathrm{MgCl}_{2}(1.2 \mathrm{mM}), \mathrm{NaH}_{2} \mathrm{PO}_{4}(1.2 \mathrm{mM}), \mathrm{NaHCO}_{3}(15.5 \mathrm{mM})$ supplemented with glucose (11.5 mM). Each strip was attached to the base with a stationary hook and tied to the isometric contraction transducer (HSE Type 372) with surgical silk. The KRS was maintained at $38^{\circ} \mathrm{C}$ and oxygenated $\left(95 \% \mathrm{O}_{2}\right.$ and $\left.5 \% \mathrm{CO}_{2}\right)$. All preparations were allowed to equilibrate for $2 \mathrm{~h}$. The force of the isometric contractions of the smooth muscle was measured every $2 \mathrm{~s}$ for $20 \mathrm{~min}$ before (basal contractions) and after OT (10-7M) and porcine (purified and gifted from Dr. O.J. Sherwood, IL, USA) or human RLX application. The track of contractions was recorded according to Wrobel et al. [22].

\section{The effect of PCBs on hormone secretion from luteal cells}

Luteal cells from six cows were incubated $\left(72 \mathrm{~h}, 38^{\circ} \mathrm{C}\right)$ separately with PCB 77 or PCB 153 (each at dose of $0.1,1$ or 10 $\mathrm{ng} / \mathrm{ml} ; \mathrm{n}=5)$. Each treatment was performed in duplicate. The time of incubation was chosen, according to previous studies with polychlorinated biphenyls $[4,31]$ and other chlorinated pesticides $[23,35,36]$. After incubation, the medium was collected into tubes containing $10 \mu \mathrm{l}$ of $0.3 \mathrm{M}$ EDTA in $1 \%$ acetylsalicylic acid [37] and stored at $-20^{\circ} \mathrm{C}$ for subsequent determination of P4 and OT in cell cultures. The concentrations of both hormones were determined by EIA. Horseradish peroxidase-labelled P4 and the biotinylated OT were used as tracers. Antisera for $\mathrm{P} 4$ and $\mathrm{OT}$, were used at final dilutions of 1:100000 and 1:25000, respectively. The standard curves for P4 and OT, ranged from 0.1 to $25 \mathrm{ng} / \mathrm{ml}$ and 7.8 to $2000 \mathrm{pg} / \mathrm{ml}$, respectively. Finally, concentration of all hormones assigned in culture media was expressed per milligram of cellular protein measured by Bradford method (1976). Both hormone concentrations and protein measurements were performed using ELISA reader (Epoch BioTek, USA).

\section{Statistical analysis}

The mean ( \pm SEM) values for contraction force were expressed in $\mathrm{mN}$ and calculated using all measurements collected every two seconds for 20 minutes. These measurements were compared by one-way ANOVA followed by the Newman-Keuls test. However, the effect of OT or RLX challenges was compared by parried t-test and the results were expressed in \% to better extension of changes or lack of effect in comparison before and after theirs substitution. All other mean $( \pm$ SEM) values were compared by one-way ANOVA for repeated measures followed by the Newman-Keuls test. The Prism 5 software (GraphPad Software, Inc., USA) was used to prepare all statistical analyses and figures. The real-time PCR Miner algorithm was used to analyse the relative mRNA quantification data [38].

\section{Results with Discussion}

Both studied congeners and E2 decreased $(\mathrm{P}<0.05)$ mRNA expression of RLX receptor in myometrium (Figure 1). In my knowledge, there is any others reports about the effect of chlorinated xenobiotics on mRNA expression of this receptor. It is worth to mentioned that high circulating $17 \beta$-estradiol is one of the factors which triggers the down-regulation in receptor of RLX during gestation in rats [39]. Hence, it was shown that both studied congeners exerts their estrogenic properties. Moreover, it can be suggested that studied estrogen-like PCBs diminish the receptivity of myometrium on inhibitor of myometrial contractions (it means RLX). Therefore, it is possible that the PCBs support increase of myometrial contractions, also in this indirectly way.

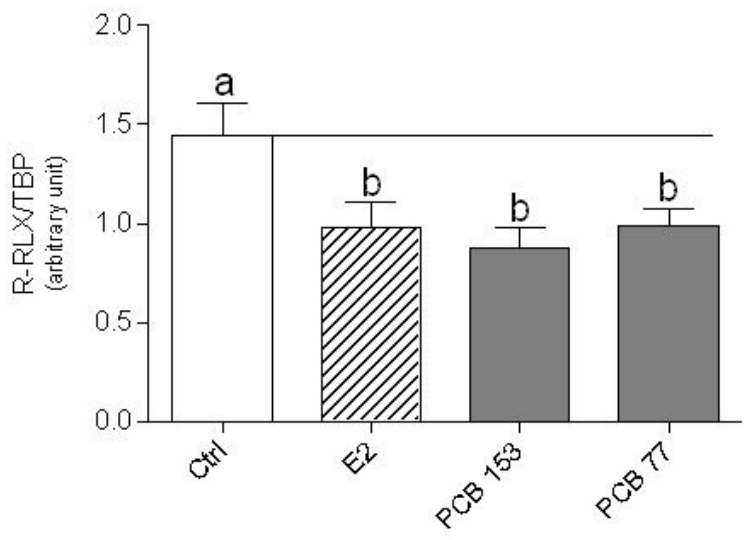

Figure. 1: The mean ( \pm SEM) mRNA expression of receptor of relaxin (R-RLX) in myometrial cells after incubation (24 h) with PCB 153, PCB 77 (both at $10 \mathrm{ng} / \mathrm{ml}$ ) and (E2, 10-7M). TBP was used as reference gen. $a-b(P<0.05)$.

Indeed, according to expectation, both, PCB 153 and PCB 77 increased $(P<0.05)$ basal contractions of longitudinal myometrial strips, during late gestation (Figures 2A, 2D), similar to their effect during estrous cycle by Wrobel et al. and early (1-3 month) pregnancy in cows. Therefore, just PCB 153 and PCB 77 were used as a kind of control and start point to further studies about the involvement of RLX in the adverse effect of xenobiotics on myometrial contractions. The force of all control strips was increased $(P<0.01)$ after OT challenge (Figures $2 B, 2 D)$, so they retain the ability to property motility and receptivity. Moreover, the similar stimulatory effect of OT was observed for strips pretreated with PCBs (Figure 2D). Unfortunately, neither porcine (Figures 2C, 2D) nor human RLX (data not showed) had effect $(P>0,05)$ on contractions of control strips of longitudinal smooth muscle after $24 \mathrm{~h}$ of incubation separately or jointly with P4 (12 ng/ml, according to Mlynarczuk et al. [40]) (Figure 2C). Similarly, both RLXs had not effect on untreated circle smooth muscle (data not showed). While the accuracy of porcine RLX $(100 \mathrm{ng} / \mathrm{ml})$ was confirmed, since it decreased the contractions of myometrial strips from swine (Figure 2E). The lack of effect of porcine RLX on bovine myometrium has been surprised, since it had used to study effect on E2, OT and P4 secretion $[34,41]$ and 
to cause a cervical dilatation $[34,42]$ in beef heifers in vivo, as well as cow RLX preparations gave reactions of identity with the porcine RLX [43]. Therefore, it is suggest that RLX from swine and human is not appropriate to use as a support of in vitro model to study the effect of xenobiotics on myometrial contractions. The next evaluation of this part of study has to be done with bovine RLX or even relaxin-like factor (RLF), since it may be functionally substituting for RLX in ruminants such as the sheep and cow [44].
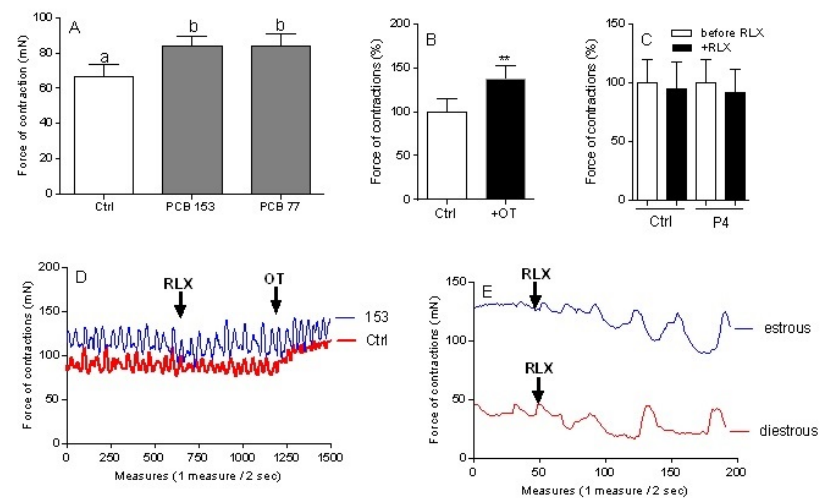

Figure. 2: $(A)$ The mean $( \pm S E M)$ basal force of myometrial strips contractions after incubation (24 h) with PCBs (10 ng/ $\mathrm{ml})$. a-d $(\mathrm{P}<0.05)$. (B) The effect of OT $(10-7 \mathrm{M})$ challenge ** $(P<0.01)$. (C) The effect of porcine RLX $(100 \mathrm{ng} / \mathrm{ml})$ challenge on force of contraction after incubation ( $24 \mathrm{~h}$ ) with P4. (D) Individual chart of contractions of myometrial strips (control and treated with PCB 153) from one cow before and after porcine relaxin (RLX; $100 \mathrm{ng} / \mathrm{ml}$ ) and oxytocin (OT; 10-7M) challenge (arrow). (E) Individual chart of contractions of myometrial strips from two swines (at estrous and diestrous) before and after porcine relaxin (RLX; $100 \mathrm{ng} / \mathrm{ml}$ ) challenge (arrow).

If the changes in direct effect of bovine RLX or RLF on myometrium pre-treated with PCBs will be confirmated, the check the effect of PCBs on amount of RLX or RLF secreted at from luteal cell cultures has to be done also. Here, the control luteal cells secreted a large amount P4 in comparison with OT, so it suggested that the P4 block was ability at studied cows. Moreover, both congeners increased $(P<0.05)$ secretion of $P 4$ and OT from these cell culture (Figure 3). Similarly, in previous study, both congeners increased OT secretion during estrous cycle [4] and PCB 77 also at early (1-3 months) pregnancy [41] Moreover, PCB 77 increased P4 secretion during estrous cycle [41]. Therefore, this experiment was rather a supplement of previous showed effect of PCBs and control of reproductive system function of studied cows.

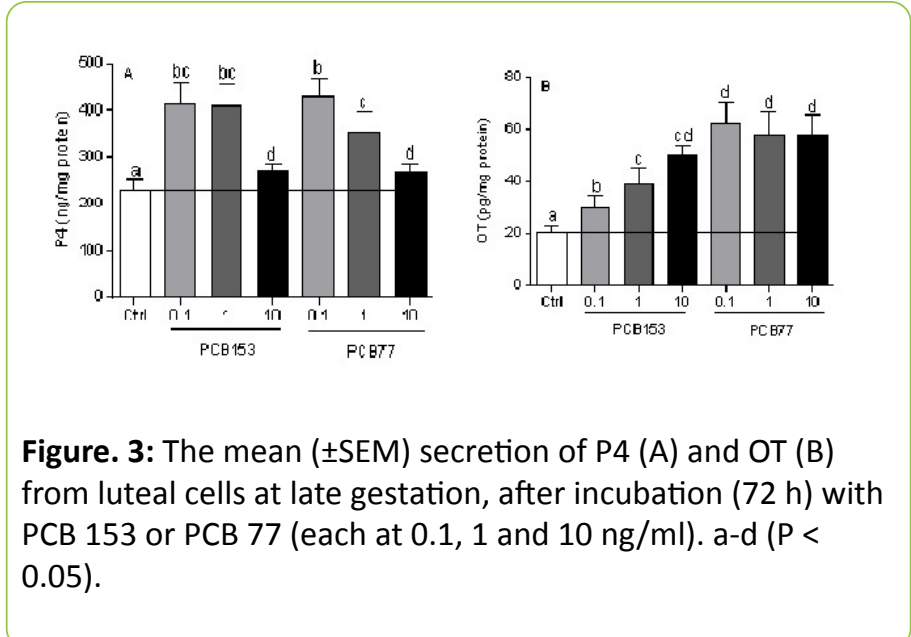

In summary PCBs can decreased the sensitivity of bovine myometrium on RLX and they changed the secretory function (P4 and OT) of luteal cells at late gestation. But the direct involvement of RLX in adverse effect of polychlorinated biphenyls on bovine myometrial contractions was not confirmated. Neither porcine nor human RLX use not developed the model to study the adverse effect of PCBs on myometrial contractions. However, the interaction between PCBs and RLX and the study about their direct effect on RLX function has to be further evaluated.

\section{Acknowledgments}

Author would like to thank for purified porcine RLX kindly gifted from Dr. O.J. Sherwood (University of Ilinois at UrbanaChampaign, IL, USA) and Dr. J. Mlynarczuk (Institute of Animal Reproduction and Food Research of the Polish Academy of Sciences, Olsztyn Poland) for obtain the luteal cells, as well as Mr. J. Klos (Institute of Animal Reproduction and Food Research of the Polish Academy of Sciences, Olsztyn Poland) for collect the uteri from swine. This study was supported by the Polish Academy of Sciences.

\section{References}

Borja J, Taleon DM, Auresenia J, Gallardo S (2005) Polychlorinated biphenyls and their biodegradation. Process Biochem 40: 1999-2013.

2. Safe SH (1993) Toxicology, structure-function relationship, and human and environmental health impacts of polychlorinated biphenyls: progress and problems. Environ Health Perspect 100: 259-268.

3. Nesaretnam K, Corcoran D, Dills RR, Darbre P (1996) 3,3',4,4'Tetrachlorobiphenyl acts an estrogen in vitro and in vivo. Mol Endocrinol 10: 923-936.

4. Mlynarczuk J, Kotwica J (2006) Influence of polychlorinated biphenyls on LH-stimulated secretion of progestereone and oxytocin from bovine luteal cells. Pol J Vet Sci 9, 101-108.

5. Krogeneas AV, Nafstad I, Skare JU, Farstad W, Hafne Al (1998) In vitro reproductive toxicity of polychlorinated biphenyl congeners 153 and 126. Reprod Toxicol 12: 575-580. 
6. Gregoraszczuk EL, Sowa M, Kajta M, Ptak A, Wójtowicz A (2003) Effect of PCB 126 and PCB 153 on incidence of apoptosis in cultured theca and granulosa cells collected from small, medium and large preovulatory follicles. Reprod Toxicol 17: 465-471.

7. Kim L, Jeon JW, Son JY, Park MK, Kim CS, et al. (2017) Monitoring and risk assessment of polychlorinated biphenyls (PCBs) in agricultural soil from two industrialized areas. Environ Geochem Health 39: 279-291.

8. Corsolini S, Sarà G (2017) The trophic transfer of persistent pollutants (HCB, DDTs, PCBs) within polar marine food webs. Chemosphere 177: 189-199.

9. Glynn AW, Wernroth L, Atuma S, Linder CE, Aune M, et al. (2000). $\mathrm{PCB}$ and chlorinated pesticide concentrations in swine and bovine adipose tissue in Sweden 1991-1997: spatial and temporal trends. Sci Total Environ 10: 195-206.

10. Kamarianos A, Karamanlis X, Goulas P, Theodosiadou E, Smokovitis A (2003). The presence of environmental pollutants in the follicular fluid of farm animals (cattle, sheep, goats, and pigs). Reprod Toxicol 17: 185-190.

11. Manning TM, Roach AC, Edge KJ, Ferrell DJ (2017) Levels of PCDD/Fs and dioxin-like PCBs in seafood from Sydney Harbour, Australia. Environ Pollut. S0269-7491: 32811-32821.

12. Polishuk ZW, Wassermann D, Wasserman M, Cucos S, Ron M (1977) Organochlorine compounds in mother and fetus during labor. Environ Res 13: 278-284.

13. Mendola P, Buck GM, Sever LE, Zielezny M, Vena JE (1997) Consumption of PCB-contaminated freshwater fish and shortened menstrual cycle length. Am J Epidemiol 146: 955-960.

14. Taylor PR, Lawrence CE, Hwang HL, Paulson AS (1984) Polychlorinated biphenyls: influense of birthweight and gestation. Am J Public Health 74: 1153-1154.

15. Berkowitz GS, Lapinski RH, Wolff MS (1996). The role of DDE and polychlorinated biphenyl levels in preterm birth. Arch Environ Contam Toxicol 30: 139-141.

16. Leoni V, Fabiani L, Marinelli G, Puccetti G, Tarsitani GF, et al. (1989) PCB and other organochlorine copounds in blood of women with or without miscarriage: a hypothesis of correlation. Ecotox Environ Safety 17: 1-17.

17. Arnold DL, Mes J, Bryce F, Karpiński K, Bickis MG, et al. (1990) A pilot study on the effects of Aroclor 1254 ingestion by rhesus and cynomolgus monkeys as a model for human ingestion of PCBs. Food Chem Toxicol 28, 847-857.

18. Tsai ML, Webb RC, Loch-Caruso R (1996) Congener-specific effects of PCBs on contractions of pregnant rat uteri. Reprod Toxicol 1 : 21-28.

19. Wrobel M, Kamiński K, Kotwica J (2005) In vitro effects of polychlorinated biphenyls (PCBs) on the contractility of bovine myometrium from the periovulatory stage of the estrous cycle. Reprod Biol 5: 303-319.

20. Tsai ML, Webb RC, Loch-Caruso R (1997) Increase of oxytocininduced oscillatory contractions by 4-hydroxy- 2',4',6'trichlorobiphenyl is estrogen receptor mediated. Biol Reprod 56: 341-347.

21. Bae J, Golden MP, Loch-Caruso R (1999). Stimulation of pregnant rat uterine contraction by the polychlorinated biphenyl (PCB) mixture Aroclor 1242 may be mediated by arachidonic acid release throught activation of phospholipase A2 enzymes. J Pharm Exp Ther 2: 1112-1120.
22. Wrobel M, Kotwica J (2006) Effect of polychlorinated biphenyls (PCBs) on basal and OT-stimulated calcium concentrations in myometrial cells in cows. Reprod Biol 5: 321-330.

23. Wrobel MH, Rękawiecki R, Kotwica J (2009) Involvement of prostaglandin F2 $\alpha$ in the adverse effect of PCB 77 on the force of contractions of bovine myometrium. Toxicology 262: 224-229.

24. Hawk HW, Conley HH (1974) Altered motility of myometrium from estrous ewes after the regulations of estrous with progestagen or prostaglandin. Theriogeneology 2: 37-46.

25. Inskeep EK (2004) Preovulatory, postovulatory, and postmaternal recognition effects of concentrations of progesterone on embryonic survival in the cow. J Anim Sci 82: E24-E39.

26. Lye SJ, Porter DG (1978) Demonstration that progesterone 'blocks' uterine activity in the ewe in vivo by a direct action on the myometrium. J Reprod Fertil 52: 87-94.

27. Smith DE, Hixon DL, Moore DW, Van Kirk EA, Alexander BM, et al. (1996) Effects of porcine relaxin on induced parturition in beef heifers. Domest Anim Endocrinol 13: 469-476.

28. Musah AH, Schwabe C, Anderson LL (1990) Relaxin and prostaglandin on oxytocin secretion from bovine luteal cells during different stages of gestation. Acta Endocrinol (Copenh) 122: 396-340.

29. Perezgrovas R, Anderson LL (1982) Effect of porcine relaxin on cervical dilatation, pelvic area and parturition in beef heifers. Biol Reprod 26: 765-776.

30. Hafez ESE (1968). Reproduction in Farm Animals, second ed. Lea\&Febiger, Philadelphia, pp. 173-205.

31. Mlynarczuk J, Kotwica J (2005). Influence of polychlorinated biphenyls on the secretion of oxytocin from bovine luteal cells and from granulosa cells obtained from the follicles of different size. Pol J Vet Sci 8: 261-267.

32. Bradford MM (1976) A rapid and sensitive method for the quantification of microgram quantities of protein utilizing the principle of protein-dye binding. Anal Biochem 72: 248-254.

33. Musah Al, Schwabe C, Anderson LL (1987). Acute decrease in progesterone and increase in estrogen secretion caused by relaxin during late pregnancy in beef heifers. Endocrinology 120: 317-324.

34. Nair VB, Samuel CS, Separovic F, Hossain MA, Wade JD (2012) Human relaxin-2: historical perspectives and role in cancer biology. Amino Acids 43: 1131-1140.

35. Wrobel MH, Grzeszczyk M, Młynarczuk J, Kotwica J (2015). The adverse effects of aldrin and dieldrin on both myometrial contractions and the secretory functions of bovine ovaries and uterus in vitro. Toxicol Appl Pharmacol 285: 23-31.

36. Wrobel MH, Mlynarczuk J (2017) Secretory function of ovarian cells and myometrial contractions in cow are affected by chlorinated insecticides (chlordane, heptachlor, mirex) in vitro. Toxicology and Applied Pharmacology 314: 63-71.

37. Meyer MD, Desnoyers GD, Oldick B, Thatcher WW, Drost M, et al. (1996). Treatment with recombinant bovine interferon-tau in utero attenuates secretion of prostaglandin $F$ from cultured endometrial epithelial cells. J Dairy Sci 79: 1375-1384.

38. Zhao S, Fernald R (2005). Comprehensive algorithm for quantitative real-time polymerase chain reaction. J Comput Biol 12: 1045-1062.

39. Vodstrcil LA, Shynlova O, Westcott K, Laker R, Simpson E, et al. (2010). Progesterone withdrawal, and not increased circulating relaxin, mediates the decrease in myometrial relaxin receptor 
(RXFP1) expression in late gestation in rats. Biol Reprod. 83: 825-832.

40. Mlynarczuk J, Wróbel MH, Kotwica J (2010) Effect of environmental pollutants on oxytocin synthesis and secretion from corpus luteum and on contractions of uterus from pregnant cows. TAAP 247: 243-249

41. Musah Al, Schwabe C, Anderson LL (1989). Relaxin regulates oxytocin secretion in late-pregnant beef heifers. Proc Soc Exp Biol Med 191:124-129.
42. Bagna B, Schwabe C, Anderson LL (1991) Effect of relaxin on facilitation of parturition in dairy heifers. J Reprod Fertil. 91:605-15.

43. Larkin LH, Suarez-Quian CA, Fields PA (1979) In vitro analysis of antisera to relaxin. Acta Endocrinol (Copenh) 92: 568-576.

44. Ivell R (1997) Biology of the relaxin-like factor (RLF). Rev Reprod 2: 133-138. 